\title{
Evaluation of the efficacy and tolerability of mandelic acid-containing cosmetic formulations for acne skin care
}

\section{Ocena skuteczności działania i bezpieczeństwa stosowania dermokosmetyków zawierających kwas migdałowy u pacjentów z trądzikiem}

\author{
Renata M. Dębowska', Aleksandra Kaszuba², Iwona Michalak², Agata Dzwigałowska', Czanita Cieścińska³, \\ Elżbieta Jakimiuk ${ }^{4}$, Joanna Zielińska ${ }^{4}$, Andrzej Kaszuba ${ }^{5}$

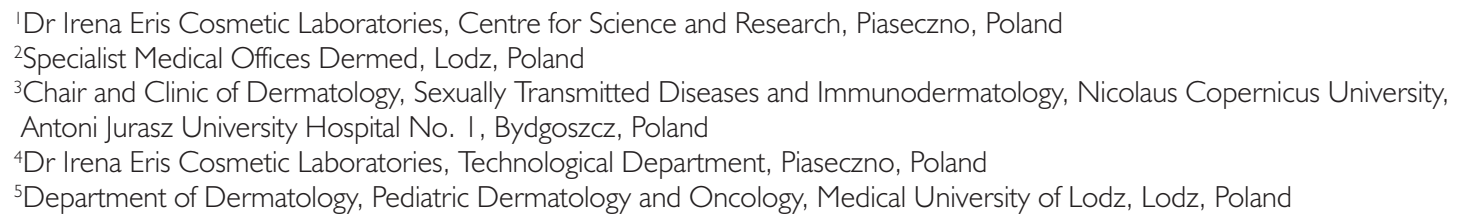

\section{KEY WORDS:}

acne vulgaris, mandelic acid, skin care.

\section{SŁOWA KLUCZOWE:} trądzik zwyczajny, kwas migdałowy, pielęgnacja skóry.

\section{ADDRESS FOR}

\section{CORRESPONDENCE:}

Renata M. Dębowska

Dr Irena Eris Cosmetic

Laboratories

Centre for Science and Research

12 Armii Krajowej St

05-500 Piaseczno, Poland

phone: +48 225417104

fax: +48228441724

e-mail: renata.debowska@

DrIrenaEris.com

\section{ABSTRACT}

Introduction. Acne vulgaris is a common, chronic skin disease that shows a characteristic clinical picture. Skin lesions occur primarily in the seborrheic areas of the body, i.e., the face, back, and chest. Mandelic acid yields very good results when used to treat excessive actinic keratosis (keratosis actinica), hyperpigmentation (lentigo solaris and melasma), and meshlike wrinkles, which are primarily caused by sun-induced aging of the skin. This therapy is well suited for the care of skin with acne vulgaris.

Objective. To evaluate the efficacy of dermo-cosmetics containing $5 \%$ or $10 \%$ mandelic acid for the skin care of patients with acne vulgaris.

Material and methods. An open study was carried out on 60 patients with papulo-pustular acne, who applied dermocosmetics to their skin for 2 months. Patients were divided into two subgroups of 30 patients each. One group was tested with a 5\% mandelic acid containing cosmetic while the other group was tested with a $10 \%$ mandelic acid containing cosmetic. After the treatment was completed, acne severity was evaluated according to the Hellgren-Vincent scale.

Results. Physical examinations performed during the study revealed a gradual improvement in the condition of the skin in both groups, with a reduction in the number of pustules, inflammatory nodules, and comedones. The proportion of patients in each group showing a reduction in disease severity according to the Hellgren-Vincent scale was similar.

Conclusions. The results of the present study show that products containing $5 \%$ or $10 \%$ mandelic acid are both safe and effective for the treatment of acne.

\section{STRESZCZENIE}

Wprowadzenie. Trądzik pospolity (acne vulgaris) jest częstą chorobą skóry o charakterystycznym klinicznie, przewlekłym przebiegu. Do- 
tyczy wszystkich grup wiekowych, ale najwięcej przypadków odnotowuje się wśród osób w wieku od 11 do 30 lat. Zmiany skórne występują głównie w okolicach łojotokowych, tzn. na klatce piersiowej, twarzy oraz skórze pleców. Terapia kwasem migdałowym daje bardzo dobre rezultaty $\mathrm{w}$ przypadku leczenia takich zmian, jak posłoneczne starzenie się skóry w postaci nadmiernego rogowacenia słonecznego (keratosis actinica), przebarwień (lentigo solaris, melasma) oraz zmarszczek siateczkowatych. Sprawdza się również w pielęgnacji skóry z trądzikiem pospolitym.

Cel pracy. Ocena skuteczności działania dermokosmetyków przeznaczonych do pielęgnacji skóry pacjentów z trądzikiem pospolitym, zawierających 5\% i 10\% kwasu migdałowego.

Materiał i metodyka. Przeprowadzono badanie otwarte, w którym 60 pacjentów z trądzikiem grudkowo-krostkowym, o nasileniu od niewielkiego do umiarkowanego, przez 2 miesiące stosowało dermokosmetyki do pielęgnacji skóry trądzikowej. Każdy z pacjentów był 3-krotnie poddany badaniu klinicznemu, w trakcie którego oceniano stan ogólny pacjenta oraz stopień nasilenia objawów przedmiotowych (w skali Hellgrena-Vincenta), liczbę zmian skórnych - grudek, krost, zaskórników, oraz stopień nasilenia łojotoku w obrębie skóry twarzy.

Wyniki. W ciągu 8 tygodni stosowania badanych produktów zaobserwowano stopniową poprawę stanu skóry, w tym zmniejszenie nasilenia trądziku, liczby grudek zapalnych, krost, zaskórników oraz nasilenia łojotoku.

Wnioski. Badane produkty, zawierające 5\% i 10\% kwas migdałowy, charakteryzują się wysokim poziomem bezpieczeństwa stosowania oraz dużą skutecznością przeciwtrądzikową.

\section{INTRODUCTION}

Acne vulgaris is a common, chronic skin disease that shows a characteristic clinical picture. The condition is initiated by so-called microcomedo lesions within the pilosebaceous unit, which may then undergo successive transformations to comedones, papules, and pustules. More severe forms of the disease involve the formation of cysts, nodular infiltrates, disfiguring scars, and skin discoloration. In most cases $(30-66 \%)$, the clinical symptoms are at their worst between the ages of 14 and 17 (for girls) or 16 and 19 years (for boys); more recently, however, the average age has risen to 20.5-26.5 years [1]. Skin lesions occur primarily in the seborrheic areas of the body, i.e., the face (99\%), back (90\%), and chest (78\%) [2].

The etiology and pathogenesis of acne are both complex and multifactorial, and the course of the disease is affected by endogenous and exogenous factors [3, 4]. Genetics, metabolism, hormone levels during puberty, and microorganisms all play a role in initiating the cascade of inflammatory reactions leading to the development of acne lesions. Acne due to its chronic nature and the location of the lesions poses big problems from a psychological point of view $[2,4-6]$.

Fruit acids are substances that have a superficial peeling action. Superficial peeling is a procedure in which the exfoliant penetrates through the entire thickness of the epidermis and of part, or all, of the papillary layer of the skin (depending on the concentration of the acid). The most frequently used fruit acids in dermatology and cosmetology are those with the shortest carbon chains; these include glycolic acid (2-hydroxy-ethane), lactic acid (2-hydroxypropanoic), and mandelic acid [7-9].

Mandelic acid (classified by the International Nomenclature of Cosmetic Ingredients (INCI) as an alpha-hydroxy acid) is harvested from the extract of bitter almonds via the hydrolysis of benzaldehyde $\left(\mathrm{C}_{6} \mathrm{H}_{5} \mathrm{CHO}\right)$. A single mandelic acid molecule comprises eight carbon atoms and is larger than a glycolic acid molecule, which contains only two. This endows mandelic acid with specific therapeutic properties. For example, the large mandelic acid molecule is absorbed very slowly through the skin, meaning that it is less irritating. Its acidity varies with temperature; its pKa is 3.4 at $25^{\circ} \mathrm{C}$, which is lower 
than that of glycolic acid $\left(3.83\right.$ at $\left.25^{\circ} \mathrm{C}\right)$. The acid has a high melting point $\left(119^{\circ} \mathrm{C}\right)$, is freely soluble in ethanol and isopropyl alcohol, and is partially soluble in water and fats. Mandelic acid exists as two optical enantiomers, which determine its pharmacological effects [10]. The exfoliating properties of mandelic acid make it a suitable component of chemical peels. A characteristic feature of mandelic acid is its progressive action, which makes it both safe and easy to apply. It also has keratolytic and bactericidal properties and regulates the sebaceous glands, which make it a suitable adjunctive treatment for acne [11].

Mandelic acid yields very good results when used to treat excessive actinic keratosis (keratosis actinica), hyperpigmentation (lentigo solaris and melasma) and mesh-like wrinkles, which are primarily due to sun exposure-induced aging of the skin. In addition, mandelic acid is one of main treatments for skin dicoloration caused by melanodermatitis, post-inflammatory hyperpigmentation, erythromelanosis follicularis, erythrosis pigmentosa faciei, drug-induced hypermelanosis, freckles and acne scars [10,11].

A mandelic acid-based chemical peel does not cause any discomfort (e.g., burning) or redness after application to the skin. Exfoliation after peeling is both gradual and gentle, meaning that patients can undertake their normal daily activities. Because the acid does not have strong phototoxic properties, it can be used throughout the year [12]. Contraindications to chemical peeling include dark skin, a tendency to form keloids, bacterial, fungal, and viral infections (e.g., herpes), and treatment with systemic retinoids within several months before treatment. Side effects are very rare, but can include redness, skin hypersensitivity and the induction of acne lesions [10-12].

\section{OBJECTIVE}

The aim of the present study was to examine the efficacy of dermocosmetics intended for use by patients with acne vulgaris. The cosmetics contained mandelic acid (5\% or $10 \%)$, along with other active substances: lemon peel extract (which is rich in polyphenols) and sweet almond proteins.

\section{MATERIAL AND METHODS}

The study involved a group of patients suffering from mild-to-moderate papulo-pustular acne, who used dermocosmetics as a part of their acne treatment. The study lasted 2 months and was conducted in accordance with the ethical standards set down in the Declaration of Helsinki 1975 (revised in 2000). All patients were fully informed about the purpose and methodology of the study, and all signed the participation agreement form. Patient data (confidential) were available to the dermatologists, who then assigned each patient a number. The numbers were used on the clinical trial cards.

Sixty patients (51 women and 9 men; aged 1260 years) were enrolled in the study. Inclusion/ exclusion criteria were based on the results of both a physical and a dermatological examination (conducted during the first visit). Skin lesions were evaluated using the Hellgren and Vincent scale [13], which takes into account erythema and the number of comedones, papules, and pustules. On this basis, the respondents who qualified for the study were individuals with moderate to intense seborrhea, who had acne changes not requiring pharmacological treatment or who had completed pharmacological treatment (with first degree, second degree or third degree acne according to the Hellgren-Vincent scale).

Patients were divided into two subgroups of 30. Each group tested a different cosmetic product. Those in group A (sensitive skin and moderately severe acne; first degree according to the Hellgren-Vincent scale) applied a cream containing 5\% mandelic acid and lemon peel extract, while those in group B (with oily skin with more severe acne; second degree according to the Hellgren-Vincent scale) applied a cream containing $10 \%$ acid and sweet almond proteins. The patients applied the product once daily (in the evening) for a period of 2 months.

Each patient underwent three separate clinical examinations, which were performed by a dermatologist.

- Screening visit (D0): Patients were assigned to the appropriate test group. Patients underwent a physical examination to assess their general condition, the severity of symptoms (on the Hellgren-Vincent scale), the number and type of skin lesions (papules, pustules, comedones and others), and severity of seborrhea on the face. Current and past treatments were noted.

- First follow-up visit (D30): After 1 month of treatment, the severity of symptoms (according to the Hellgren-Vincent scale), the number of skin lesions (papules, pustules, comedones and others), and severity of seborrhea on the face were reassessed. Any side effects were reported and noted.

- Second follow-up visit (D60): After 2 months of treatment, the investigator made a final assessment of severity of the symptoms (according to the Hellgren-Vincent scale), the number of skin lesions, and severity of seborrhea on the face. In addition, patients completed a survey in which they assessed the efficacy of the investigational product, and gave their subjective impressions. Any side effects were noted. 


\section{RESULTS}

\section{Tolerance of cosmetic preparations}

Nine patients in group A (5\% mandelic acid) experienced skin irritation, mainly in the form of mild erythema and mild epidermal exfoliation. One of the nine patients experienced conjunctival irritation and watery eyes. All symptoms were transient and none of the patients dropped out of the study.

Nine patients in group B (10\% mandelic acid) suffered skin irritation, manifesting as mild erythema and mild epidermal exfoliation. Two of these patients also reported itchy skin. All symptoms were transient and none of the patients dropped out of the study.

\section{Clinical assessment of treatment efficacy}

Physical examinations in both groups performed during the study noted a gradual improvement in the condition of the skin, with a reduction in the number of pustules, inflammatory nodules, and comedones (Table 1). The most striking result was the reduction in the number of pustules. At the end of the study, there was a $60 \%$ reduction in the number of pustules in group A and a $61 \%$ reduction in group B (Table 1). After 60 days of treatment, the severity of seborrhea was reduced by $42 \%$ in group A and by $37 \%$ in group B (Figure $1)$. In each group, the reduction in disease severity according to the Hellgren-Vincent scale was similar (19\% for group A and 18\% for group B) (Figure 2). The proportion of patients in each group that showed improvement after 60 days was significant (Table 2).

\section{Self-assessment of treatment efficacy}

Patients were also asked to complete a detailed questionnaire after the treatment. The results showed that, in group A, $88 \%$ of the respondents would like to use the product containing $5 \%$ mandelic acid again and, in group B, $82 \%$ of respondents would like to use the product containing $10 \%$ mandelic acid again.

Of the patients in group A, 76\% reported regression of existing acne lesions, reduction in the formation of new lesions, and reduction in the size of sebaceous glands. Also, 84\% reported reduced sebum secretion. Of the patients in group B, 64\% reported reduction in sebum secretion, $61 \%$ confirmed the

Table I. Clinical assessment of acne symptoms carried out by physicians during 60-day application of mandelic acid creams

Tabela I. Kliniczna ocena nasilenia objawów trądziku w grupie A i B przeprowadzona przez lekarza podczas 60-dniowego stosowania kremów z kwasem migdałowym

\begin{tabular}{lccccc} 
Variable & D0 (\%) & \multicolumn{2}{c}{$\begin{array}{c}\text { Group A } \\
\text { Group B }\end{array}$} \\
\cline { 3 - 6 } & & 5\% mandelic acid cream & 10\% mandelic acid cream \\
\hline Amount of inflammatory nodules & 100 & D30 (\%) & D60 (\%) & D30 (\%) & D60 (\%) \\
\hline Amount of pustules & 100 & 57 & 64 & 81 & 71 \\
\hline Amount of comedones & 100 & 83 & 77 & 89 & 39 \\
\hline
\end{tabular}

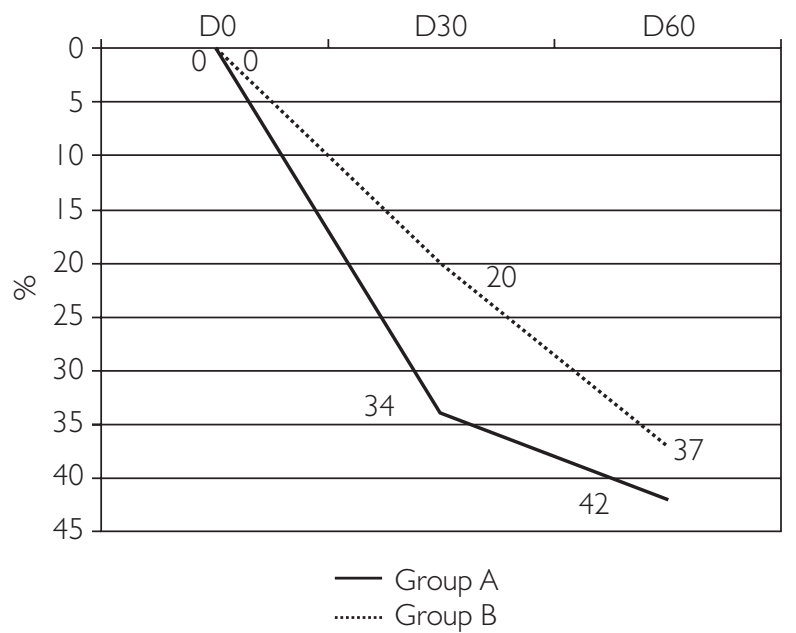

Figure I. Reduction of the severity of seborrhea

Rycina I. Zmniejszenie stopnia nasilenia tojotoku

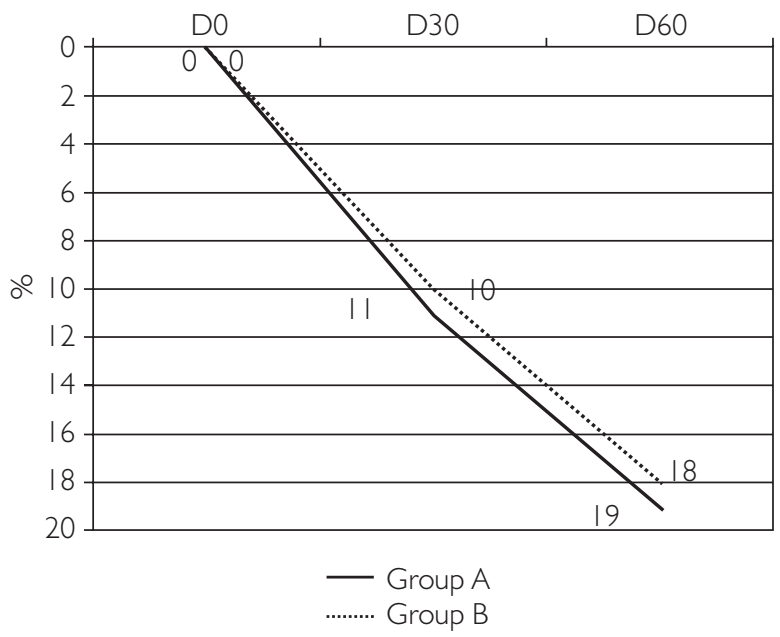

Figure 2. Reduction of the severity of acne according to HellgrenVincent scale

Rycina 2. Zmniejszenie stopnia nasilenia trądziku w skali Hellgrena-Vincenta 
Table 2. Percentage of volunteers who showed clinical improvement - a reduction of acne symptoms after 60 days of application of creams

Tabela 2. Odsetek ochotników, u których stwierdzono poprawę klinicznq - zmniejszenie nasilenia objawów trądziku po 60 dniach stosowania kremów

\begin{tabular}{|c|c|c|}
\hline Clinical improvement & $\begin{array}{l}\text { Percentage of volunteers } \\
\text { in group A } \\
5 \% \text { mandelic acid cream }\end{array}$ & $\begin{array}{l}\text { Percentage of volunteers } \\
\text { in group B } \\
10 \% \text { mandelic acid cream }\end{array}$ \\
\hline Reduction in the amount of inflammatory nodules & 93 & 90 \\
\hline Reduction in the amount of pustules & 60 & 60 \\
\hline Reduction in the amount of comedones & 57 & 50 \\
\hline Reduction of the severity of seborrhea & 83 & 70 \\
\hline
\end{tabular}

exfoliating action of the product, and $68 \%$ stated that the product made the skin smoother. More than a half of respondents reported regression of existing acne lesions (57\%) and a reduction in the size of sebaceous glands $(54 \%)$.

\section{DISCUSSION}

Both of the tested products were safe. The only side effect noted during the 2-month study was mild skin irritation. These symptoms occurred only in patients with sensitive skin, were transient, and did not require discontinuation of treatment. According to physicians, such reactions are consistent with the action of mandelic acid, and are regarded as a normal side effect of anti-acne products.

During the 2-month study, both groups experienced reduction in the signs and severity of acne (assessed by the Hellgren-Vincent scale). We previously reported that a face gel wash and a micellar solution containing mandelic acid reduced acne symptoms [13]. In addition, Abels et al. reported that twicedaily application of a topical glycolic acid-containing cleansing product ( $\mathrm{pH} 4$ ) for 6 weeks led to a significant improvement of mild acne [14]. However, the patients in our previous study were treated with wash-out cosmetics in addition to cream containing azelaic acid and sodium salicylate. The reduction of acne symptoms was due to the combined action of both cosmetics. Here, we found that creams containing $5 \%$ or $10 \%$ mandelic acid both reduced the severity of acne and gradually improved the overall condition of the skin.

At present, few topical cosmetic products contain mandelic acid. Mandelic acid is used as a medical peel, and yields very good results in treatment of aging, hyperpigmentation, or acne scars [15-17]. However, the number of leave-on cosmetics containing poly-hydroxy acids (PHAs) is increasing [18]. The most common PHAs are glycolic acid, salicylic acid, lactobionic acid, and citric acid (used at concentrations of $1-10 \%(\mathrm{w} / \mathrm{v}))$ [19-22]. The data presented herein show that topical application of a cream containing mandelic acid is a safe and effective treatment for acne.

\section{CONCLUSIONS}

A cream containing $5 \%$ mandelic acid may be recommended for the treatment of patients with sensitive skin and moderately severe acne; the treatment has a mild exfoliating effect. The product also contained lemon peel extract, which plays a role in softening and whitening of skin.

A cream containing $10 \%$ mandelic acid may be recommended to patients with an oily or mixed skin type and more severe acne. This preparation also contained sweet almond proteins, which help to smooth the skin. This product can also be recommended for the treatment of aging, dehydrated, or sensitive skin, with visible furrows and wrinkles, as well as for cases of thinning of the epidermis and for flabby skin (with visibly reduced flexibility), discolored skin, and skin showing increased sensitivity to external factors (UV radiation, free radicals, and pollution).

The results of the present study show that products containing $5 \%$ or $10 \%$ mandelic acid are both safe and effective for the treatment of acne.

\section{Conflicts of interest}

The research was funded by the Dr Irena Eris Cosmetic Laboratories. The sponsor prepared the cosmetic formulations and agreed with and accepted the clinical methods used by the dermatologists. The institution in which the tests were conducted received payment in accordance with the contract. The test results were reported and summarized by dermatologists.

\section{References}

1. Zalewska-Janowska A.: Adult acne - novel entity or the old disease re-discovered? Dermatol Estet 2012, 14, 162-166.

2. Wolska H., Gliński W., Placek W.: Acne vulgaris - pathogenesis and treatment. Consensus PTD. Przegl Derm 2007, 94, 171-178.

3. Bhambri S., Del Rosso J.Q., Bhambri A.: Pathogenesis of acne vulgaris: recent advances. J Drugs Dermatol 2009, 8, 615-618. 
4. Ramos-e-Silva M., Carneiro S.C.: Acne vulgaris: review and guidelines. Dermatol Nurs 2009, 2, 63-68.

5. Garg A., Chren M.M., Sands L.P., Matsui M.S., Marenus K.D., Feingold K.R., et al: Psychological stress perturbs epidermal permeability barrier homeostasis. Implications for the pathogenesis of stress-associated skin disorders. Arch Dermatol 2001, 137, 53-59.

6. Braun-Falco O., Plewig G., Wolff H.H., Burgdorf W.H.C.: Dermatology. Springer-Verlag, Berlin-Heidelberg-New York, 2000.

7. Bieniek A., Białynicki-Birula R.: Chemical peels. Part I. The principle of operation, historical background, types of peels, side-effects. Dermatol Klin 2004, 6, 109-114.

8. Broniarczyk-Dyła G., Wawrzycka-Kaflik A., Prusińska-Bratoś M.: The effect of the pharmacological activity of chemical compounds used in chemical peels. Dermatol Estet 2004, 6, 19-23.

9. Bieniek A, Białynicki-Birula R., Barancewicz-Łosek M., Szepietowski J., Kuniewska B., Okulewicz-Gojlik D.: Chemical peels. Part II. Biological properties, usage and side effects glycolic acid peels and resorcinol. Dermatol Klin 2004, 6, 191-195.

10. Chlebus E.: Mandelic acid - a new medical peel. Dermatologia 2006, 282.

11. Oskarbski G.V.: Mandelic acid - a new tool in aesthetic medicine. Med Estet Przeciwst 2004, 3, 169-172.

12. Broniarczyk-Dyła G., Fornalczyk-Wachowska E.: The possibility of reducing the intensity off acial skin discoloration after using modified mandelic acid peels. Dermatol Estet 2007, 2, 99-103.

13. Tazbir M., Pastuszka M., Kaszuba A.: Evaluation of the efficacy and tolerability of cosmetic preparations for acne skin care. Dermatol Estet 2011, 3, 167-174.

14. Abels C., Reich H., Knie U., Werdier D., Lemmnitz G.: Significant improvement in mild acne following a twice daily application for 6 week of an acidic cleansing product (pH 4). J Cosmet Dermatol 2014, 13, 103-108.
15. Wójcik A., Kubiak M., Rotsztejn H.: Influence of azelaic and mandelic acid peel on sebum secretion in ageing woman. Postep Derm Alergol 2013, 30, 140-145.

16. Taylor M.B., Yanaki J.S., Draper D.O., Shurtz J.C., Coglianese M.: Successful short-term and long-term treatment of melisma and postinflammatory hyperpigmentation using vitamin $\mathrm{C}$ with full-face ionophoresis mask and a mandelic/malic acid skin care regimen. J Drugs Dermatol 2013, 12, 45-50.

17. Garg V.K., Sinha S., Sarkar R.: Glycolic acid peels versus salicylic-mandelic acid peels in active acne vulgaris and post-acne scarring and hyperpigmentation: a comparative study. Dermatol Surg 2009, 35, 59-65.

18. Grimes P.E., Green B.A., Wildnauer R.H., Edison B.L.: The use of polyhydroxy acids (PHAs) in photoaged skin. Cutis 2004, 73, 3-13.

19. Tasic-Kostov M., Savic S., Lukic M., Tamburic S., Pavlovic M., Vuleta G.: Lactobionic acid in a natural alkylpolyglucoside-based vehicle: assessing safety and efficacy aspects in comparison to glycolic acid. J Cosmet Dermatol 2010, 9, 3-10.

20. Baumann L.S., Oresajo C., Yatskayer M., Dahl A., Figueras K.: Comparison of clindamicyn 1\% and benzoyl peroxide $5 \%$ gel to a novel composition containing salicylic acid, capryloyl salicylic acid, HEPES, glycolic acid, citric acid and dioic acid in the treatment of acne vulgaris. J Drugs Dermatol 2013, 12, 266-269.

21. Masini F., Ricci F., Fossati B., Frascione P., Capizzi R., De Waure C., et al: Combination therapy with retinaldehyde $(0.1 \%)$ glycolic acid $(6 \%)$ and efectiose $(0.1 \%)$ in mild to moderate acne vulgaris during the period and sun exposure - efficacy and skin tolerability. Eur Rev Med Pharmacol Sci 2014, 18, 2283-2286.

22. Bhatia A.C, Jimenez F.: Rapid treatment of mild acne with a novel skin care system containing 1\% salicylic acid, $10 \%$ buffered glycolic acid, and botanical ingredients. J Drugs Dermatol 2014, 13, 678-683.

Received: 4 III 2015 r.

Accepted: 6 VII 2015 r. 